\title{
The emergy synthesis for the Province of Pescara (Italy) and strategic choices for a sustainable development
}

\author{
M. Di Donato, A. Galli \& F. M. Pulselli \\ Department of Chemical and Biosystems Sciences, \\ University of Siena, Italy
}

\begin{abstract}
This paper shows an appraisal of local sustainability through an environmental accounting method applied to a region with reference to its population, human activities, natural cycles, infrastructures and other settings. Environmental resources locally used, whether directly or indirectly, from both renewable energy flows and storages of material are investigated.

In this paper the Emergy Synthesis is applied to the Province of Pescara (Italy) and its districts, in order to evaluate the main flows of energy and materials that locally supply the territorial system, including human systems, with reference to their actual environmental cost.

Once expressed in units of the same form of energy through the emergy evaluation, categories of resource consumptions and systems of varying scales and organization are compared. Furthermore, indexes of environmental performance based on emergy are calculated.

Keywords: emergy analysis, sustainability indicators, environmental accounting.
\end{abstract}

\section{Introduction}

This research proposes the results of an environmental assessment of a territorial system, which will be conducted through the emergy synthesis. The system, in fact, may be seen as an open thermodynamic system interacting and depending on the natural environment, whose existence would not be possible without the activity of survival systems.

Emergy synthesis is an environmental accounting method based on thermodynamics that enables the integration of economic and ecological aspects: 
the final goal is to test the global behaviour of the system in relation to use and consumption of natural resources.

Statistical data from local and regional databases was used to monitor the matter and energy flows, as well as the main economic activities and income sources.

The use of emergy evaluation in a territorial system has the goal to provide an overall view of the considered system and to evaluate (and quantify) its environmental performance through sustainability indicators; this allows policy makers to make choices and adjustments in order to obtain the sustainability of the system or, at least, a better environmental performance.

Hence, reading the results of this thermodynamic methodology, it is possible to steer policy, focusing on local peculiarities and needs.

An integrated evaluation of the main flows of natural and economical resources that feed a region enables to understand how it is evolving towards sustainable pathways.

Methods used for environmental analysis are characterized by a qualitative approach in determining the effects of human activities on ecosystems, while natural capital is underestimated, or even excluded, from conventional neoclassical economic assessments.

For this reason, we need tools able to overcome classical approaches based on single criterions. Methodologies and indicators must offer the transition from a reductionist to an holistic and ecological approach.

This proposal also focuses on the principles of Ecological Economics, which considers economy as an aspect of a whole ecological and social fabric, a living system made of people interacting with each other and with the natural environment.

Ecological Economics faces the challenges imposed by the bio-physical laws ruling the planet and considers economic systems as open systems belonging to a broader ecological system. This approach implies the awareness of limits to economic growth.

Economy is in fact constantly changing and evolving, depending on the mutable ecological and social systems in which it is integrated.

Odum's emergy synthesis is a methodology oriented to the holistic study of systems; it offers an integrated economic, ecological and thermodynamic evaluation of an environmental and/or productive system.

The purpose of this methodology is the study, through an energetic and systemic perspective, the organization of thermodynamically open systems, that can trade matter and energy with the external environment. The main goals are: assessment of the energetic externally forces applied to the system and which drive its evolution; evaluation of the role of natural resources in production cycles; an evaluation of the work of the biosphere in the global dynamics of anthropic systems; development of integrated economic environmental accounting; processing thermodynamic indicators of environmental yield, impact and sustainability.

This work deals with the emergy analysis of Province of Pescara (Central Italy). 
Much statistical data has been collected on the scale of six sub-areas (namely Costa, Crinale Centrale, Vestina, Tremonti, Majella, Gransasso) so that the location of consumption, activities and land use, achieves a higher level of accuracy. Boundaries of sub-areas in the Province have been traced with reference to the Master Plan of the Province, in order to respect local economic and social dimensions and their characteristics. In this way, an appraisal of sustainability may respond to any local area within the boundaries of the Province.

\section{Methodology}

The concept of emergy is based on the assessment of all the natural resources that have been used to provide a certain product or process. For this reason, the name emergy means energy memory and it works to give a measure of quantity and also quality of energy.

Solar Emergy is the available solar energy used up directly and indirectly to make a service or product and is measured in solar emjoules, abbreviated sej. Although this basic concept is quite straightforward, its implications are potentially profound: H.T. Odum pioneered the development and use of emergy and presented it as a way of understanding the behaviour of self-organized systems. Emergy analysis considers all systems to be networks of energy flows and determines the emergy value of systems involved.

Since solar energy is the main energy input to the Earth, all other energies are scaled to solar equivalents to give common units. Other kinds of energy existing on the Earth can be derived from this main source, through energy transformations. Even the economy can be incorporated to this energy flow network since "wealth directly and indirectly comes from environmental resources measured by emergy" (Odum [1]).

An important concept in emergy analysis is Solar Transformity, defined as "the Solar Emergy required to make $1 \mathrm{~J}$ of a service or product" (Odum [1]). Solar Transformity is measured in sej/J. The Solar Transformity of a product is its Solar Emergy divided by its available energy. When an item is expressed in units different than joules, for instance grams, the quality factor is emergy/mass (sej/g).

From a practical point of view, transformity is useful as a convenient way of determining the emergy of commonly used resources and commodities. Most case studies in the literature rely on the transformities calculated by Odum and co-workers to calculate the emergy of their inputs. Transformity is a possible measure of the quality of energy and it is useful to compare different kinds of energy by using a common unit.

Since the early 1980s, emergy analysis have been used widely to analyze systems as diverse as ecological, industrial, economic; the analysis of fluxes by the emergy methodology defines, in quantity and quality, the main exchanges of energy and matter, classifying these fluxes according to their origin and destination. 
The outcomes of the analysis will deal with the character of the territorial system revealing how many resources are locally available or otherwise imported by the outside.

Furthermore, while fluxes are drawn in a diagram as kinds of vectors identified for their origin and direction, a second classification is made according to the renewability or non-renewability of their sources.

The main steps of the emergy analysis of the Province of Pescara are: identification of the boundaries of the study area that correspond to the administrative territory of the Province of Pescara; research of statistical data dealing with the anthropic activities taking place in the territory (productions, consumptions, inputs, outputs, market, etc.) and physical and geo-morphologic features (solar energy, rain, soil erosion, mineral sinks, water, etc.). All data refers to the year 2001; the calculation of matter and energy flows and the conversion of them into emergy by means of suitable transformities.

Finally there is an overview on the total emergy flows supplying the system.

Once the main inflows have been identified and the total emergy driving a process has been evaluated, a set of indices and ratios can be calculated. These indices are useful to study and compare processes under human control, where a sustainable pattern is not guaranteed and choices have to be supported by careful consideration of many different parameters.

Three main emergy flows can be recognized: renewable flows from within $(R)$, non-renewable flows from within $(N)$, and flows imported from outside the system (feedback flows, $F$ ), sometimes referred to as purchased flows. The characteristics of emergy flows make it possible to calculate different indices for monitoring system's behaviour.

In this case study four indicators can be defined as follows. The environmental loading ratio $(E L R)$, is the ratio of purchased $(F)$ and nonrenewable indigenous emergy $(N)$ to renewable environmental emergy $(R)$. It is an indicator of the pressure of the process on the local ecosystem and can be considered a measure of the ecosystem stress due to human activity.

The emergy investment ratio $(E I R)$ is the ratio of the emergy from outside $(F)$ to the local emergy flows $(R+N)$. It shows if the process is a good user of the emergy that is invested, in comparison with alternatives. The empower density $(E D)$ is the emergy per unit area. A high value of this index is found in areas where emergy is concentrated, such as cities and industrial sites. In such cases the available area can become a limiting factor for development. This index is generally low in rural or undeveloped areas. In general, for equivalent processes, the higher the empower density, the higher the environmental stress.

The emergy per person $(E p P)$, given by the ratio of total emergy to the population is an index of the standard of living which includes environmental and economic contributions to the quality of life in terms of the availability of resources and goods.

\section{Results and discussion}

The general framework of the Province is characterized by an area with mining industry (Crinale Centrale) with high emergy flows and by an area (Costa) with 
high population density and relevant economic activities and high environmental impact.

The results obtained for the Province give information about the resources exploitation in the territory according to their eMergy values.

In general, the area is almost dependent on external inputs such as electricity, food items and other goods.

Statistical data is then collected, along with detailed information on local production and consumption, imports and exports, and the economy, as well as on local geomorphology (solar irradiation, rain, soil erosion, ore deposits, water, etc.). Quantities and equivalent emergy values have been ordered into tables that distinguish different classes of resources.

In Table 1, some inputs are quantified (in $\mathrm{J} / \mathrm{yr}$ or $\mathrm{g} / \mathrm{yr}$ ) and equivalent amounts of emergy are gathered in groups as follows: local renewable $\mathrm{R}$ - local nonrenewable $\mathrm{N}$ - imported fuels and energy $\mathrm{F} 1$. In Table 2, the imports of goods and services are quantified and the equivalent amounts of emergy are classified as F2. The transformities of each entry are reported on relative rows with the corresponding reference: $a$ (Odum et al. [2]), $b$ (Tiezzi [3]), $c$ (Bastianoni et al. [4]), $d$ (Ulgiati et al. [5]), $e$ (Bastianoni et al. [6]), $f$ (Brown and Arding [7]), $g$ (Tiezzi [8]), $h$ (Ulgiati et al. [9]), $i$ (Tiezzi [10]), $j$ (Odum [11]), $k$ (Odum and Odum [12]), $l$ (Odum and Arding [13]), $m$ (Odum and Odum [14]), $n$ (Bjorklund et al. [15]), o (Odum [1]), $p$ (Bastianoni et al. [16]). Values are in scientific format (for example, $1.50 \mathrm{E}+2$ means $1.50 \times 10^{2}$ that is equivalent to 150 ).

Table 1: $\quad$ Emergy evaluation of indigenous resources $(\mathrm{R}, \mathrm{N})$ and imported fuels (F1) for the Province of Pescara, year 2001.

\begin{tabular}{|c|c|c|c|c|c|c|}
\hline No. & Item & $\begin{array}{l}\text { Amount } \\
\text { (unit/yr) }\end{array}$ & Unit & $\begin{array}{c}\text { Solar Transformity } \\
\text { (sej/unit) }\end{array}$ & Ref. & $\begin{array}{c}\text { Solar Emergy } \\
\text { (sej/yr) }\end{array}$ \\
\hline 1 & Sunlight & $5.01 \mathrm{E}+18$ & $\mathrm{~J} / \mathrm{yr}$ & $1.00 \mathrm{E}+00$ & a & $5.01 \mathrm{E}+18$ \\
\hline 2 & Rain & $1.05 \mathrm{E}+15$ & $\mathrm{~g} / \mathrm{yr}$ & $1.45 \mathrm{E}+05$ & a & $1.52 \mathrm{E}+20$ \\
\hline 3 & Wind, kinetic energy & $5.71 \mathrm{E}+14$ & $\mathrm{~J} / \mathrm{yr}$ & $2.47 \mathrm{E}+03$ & a & $1.41 \mathrm{E}+18$ \\
\hline 4 & Waves & $1.03 E+15$ & $\mathrm{~J} / \mathrm{yr}$ & $5.10 \mathrm{E}+04$ & a & $5.27 \mathrm{E}+19$ \\
\hline 5 & Tide & $3.39 \mathrm{E}+10$ & $\mathrm{~J} / \mathrm{yr}$ & $7.39 \mathrm{E}+04$ & a & $2.50 \mathrm{E}+15$ \\
\hline 6 & Geothermal heat & $1.76 \mathrm{E}+15$ & $\mathrm{~J} / \mathrm{yr}$ & $3.02 \mathrm{E}+04$ & a & $5.30 \mathrm{E}+19$ \\
\hline 7 & Soil erosion & $2.91 \mathrm{E}+14$ & $\mathrm{~J} / \mathrm{yr}$ & $1.24 \mathrm{E}+05$ & a & $3.61 \mathrm{E}+19$ \\
\hline 8 & Water, consumptions & $2.85 \mathrm{E}+13$ & $\mathrm{~g} / \mathrm{yr}$ & $1.95 \mathrm{E}+06$ & $b$ & $5.55 \mathrm{E}+19$ \\
\hline 9 & Materials from mining & $5.10 \mathrm{E}+12$ & $\mathrm{~g} / \mathrm{yr}$ & $1.68 \mathrm{E}+09$ & a & $8.56 \mathrm{E}+21$ \\
\hline 10 & Electricity use & & & & & \\
\hline & import & $1.30 \mathrm{E}+15$ & $\mathrm{~J} / \mathrm{yr}$ & $2.07 \mathrm{E}+05$ & $p$ & $2.69 \mathrm{E}+20$ \\
\hline & thermoelectric & $3.51 \mathrm{E}+15$ & $\mathrm{~J} / \mathrm{yr}$ & $2.07 \mathrm{E}+05$ & $p$ & $7.26 \mathrm{E}+20$ \\
\hline & hydroelectric & $9.98 \mathrm{E}+13$ & $\mathrm{~J} / \mathrm{yr}$ & $1.06 \mathrm{E}+05$ & $p$ & $1.06 \mathrm{E}+19$ \\
\hline 11 & Gasoline and diesel & $7.79 \mathrm{E}+15$ & $\mathrm{~J} / \mathrm{yr}$ & 1.11E+05 & o & $8.65 \mathrm{E}+20$ \\
\hline 12 & Fuel oil, LPD and lubrificants & $1.63 \mathrm{E}+15$ & $\mathrm{~J} / \mathrm{yr}$ & $9.30 \mathrm{E}+04$ & $c$ & $1.52 \mathrm{E}+20$ \\
\hline 13 & Natural gas & $4.29 \mathrm{E}+15$ & $\mathrm{~J} / \mathrm{yr}$ & $6.72 \mathrm{E}+04$ & $c$ & $2.88 \mathrm{E}+20$ \\
\hline \multicolumn{6}{|c|}{ RENEWABLE RESOURCES, R (sum of items $2,5,6$ and 10 c) } & $2.16 \mathrm{E}+20$ \\
\hline \multicolumn{6}{|c|}{ NON RENEWABLE LOCAL RESOURCES, $\mathbf{N}$ (sum of items 7, 8 and 9) } & $8.66 \mathrm{E}+21$ \\
\hline \multicolumn{6}{|c|}{ IMPORTED RESOURCES (ENERGY and FUELS), F1 (sum of items $10 \mathbf{a}, 10 \mathbf{b}, 11,12$ and 13) } & $2.30 \mathrm{E}+21$ \\
\hline
\end{tabular}

A detailed analysis is given in Table 3; in this table, in particular, there is a summary of the main emergy flows and indices for the Province of Pescara and for six districts (sub-areas). 
Table 2: Emergy evaluation of imported goods and materials (F2) for Province of Pescara, year 2001.

\begin{tabular}{|c|c|c|c|c|c|c|}
\hline No. & Item & $\begin{array}{l}\text { Amount } \\
\text { (unit/yr) }\end{array}$ & Unit & $\begin{array}{l}\text { Transformity } \\
\text { (sej/unit) }\end{array}$ & Ref. & $\begin{array}{c}\text { Solar Emergy } \\
\text { (sej/yr) }\end{array}$ \\
\hline & AGRICULTURE & & & & & \\
\hline 1 & Cereals & $6.08 \mathrm{E}+12$ & $\mathrm{~J} / \mathrm{yr}$ & 2.67E+05 & $d$ & $1.62 E+18$ \\
\hline 2 & Legumes & $3.37 \mathrm{E}+13$ & $\mathrm{~J} / \mathrm{yr}$ & $1.39 \mathrm{E}+05$ & e & $4.68 \mathrm{E}+18$ \\
\hline 3 & Fruits & $6.31 \mathrm{E}+12$ & $\mathrm{~J} / \mathrm{yr}$ & $4.82 \mathrm{E}+05$ & $d$ & $3.04 \mathrm{E}+18$ \\
\hline 4 & Vegetables & $2.93 \mathrm{E}+11$ & $\mathrm{~J} / \mathrm{yr}$ & $3.19 E+06$ & $f$ & $9.36 \mathrm{E}+17$ \\
\hline 5 & Seeds & $7.49 \mathrm{E}+13$ & $\mathrm{~J} / \mathrm{yr}$ & $1.33 E+06$ & $d$ & $9.95 E+19$ \\
\hline 6 & Spices and tabacco & $3.80 \mathrm{E}+12$ & $\mathrm{~J} / \mathrm{yr}$ & $3.36 \mathrm{E}+05$ & $f$ & $1.28 \mathrm{E}+18$ \\
\hline \multirow[t]{3}{*}{7} & Plants and flowers & $6.56 \mathrm{E}+08$ & $\mathrm{~g} / \mathrm{yr}$ & $4.74 \mathrm{E}+09$ & $g$ & $3.11 \mathrm{E}+18$ \\
\hline & & & & & & $1.14 \mathrm{E}+20$ \\
\hline & BREEDING, HUNTING and FISHING & & & & & \\
\hline 8 & Animals & 1.77E+14 & $\mathrm{J} / \mathrm{yr}$ & $5.33 \mathrm{E}+06$ & $h$ & $9.44 \mathrm{E}+20$ \\
\hline 9 & Woods & $8.38 \mathrm{E}+09$ & $\mathrm{~g} / \mathrm{yr}$ & $1.68 \mathrm{E}+08$ & $f$ & $1.41 \mathrm{E}+18$ \\
\hline \multirow[t]{3}{*}{10} & Hunting and fishing & $1.91 \mathrm{E}+09$ & $\mathrm{~g} / \mathrm{yr}$ & 2.27E+08 & $i$ & $4.34 \mathrm{E}+17$ \\
\hline & & & & & & $9.45 \mathrm{E}+20$ \\
\hline & MINING INDUSTRY & & & & & \\
\hline 11 & Metal minerals & $1.81 \mathrm{E}+08$ & $\mathrm{~g} / \mathrm{yr}$ & $5.81 \mathrm{E}+09$ & $h$ & $1.05 \mathrm{E}+18$ \\
\hline \multirow[t]{3}{*}{12} & Non metal minerals & $9.09 \mathrm{E}+10$ & $\mathrm{~g} / \mathrm{yr}$ & $2.82 \mathrm{E}+09$ & $j$ & $2.56 \mathrm{E}+20$ \\
\hline & & & & & & $2.58 \mathrm{E}+20$ \\
\hline & MANIFACTURING INDUSTRY & & & & & \\
\hline \multirow[t]{4}{*}{13} & Food industry & & & & & \\
\hline & human & $1.39 \mathrm{E}+15$ & $\mathrm{~J} / \mathrm{yr}$ & $5.33 \mathrm{E}+06$ & $h$ & $7.39 \mathrm{E}+21$ \\
\hline & non human & $8.04 \mathrm{E}+13$ & $\mathrm{~J} / \mathrm{yr}$ & $4.49 \mathrm{E}+05$ & - & $3.61 \mathrm{E}+19$ \\
\hline & beverages & $1.55 \mathrm{E}+10$ & $\mathrm{~g} / \mathrm{yr}$ & 4.23E+09 & - & $6.56 \mathrm{E}+19$ \\
\hline 14 & Tabacco industry & - & $\mathrm{J} / \mathrm{yr}$ & $1.76 \mathrm{E}+05$ & $h$ & - \\
\hline 15 & Leather industry & $1.29 \mathrm{E}+12$ & $\mathrm{~J} / \mathrm{yr}$ & $1.44 \mathrm{E}+07$ & $k$ & $1.87 \mathrm{E}+19$ \\
\hline 16 & Textile industry & $3.91 \mathrm{E}+14$ & $\mathrm{~J} / \mathrm{yr}$ & $6.38 \mathrm{E}+06$ & $f$ & $2.50 \mathrm{E}+21$ \\
\hline 17 & Furniture and clothing industry & $3.99 \mathrm{E}+13$ & $\mathrm{~J} / \mathrm{yr}$ & $6.38 \mathrm{E}+06$ & $f$ & $2.54 \mathrm{E}+20$ \\
\hline 18 & Wood and cork industry & $3.47 \mathrm{E}+10$ & $\mathrm{~J} / \mathrm{yr}$ & $5.86 \mathrm{E}+04$ & 1 & $2.04 \mathrm{E}+15$ \\
\hline 19 & Paper industry & $5.91 \mathrm{E}+15$ & $\mathrm{~J} / \mathrm{yr}$ & $3.61 \mathrm{E}+05$ & $f$ & $2.14 \mathrm{E}+21$ \\
\hline 20 & Graphic industy & $9.42 \mathrm{E}+11$ & $\mathrm{~J} / \mathrm{yr}$ & $3.61 \mathrm{E}+05$ & $f$ & $3.40 \mathrm{E}+17$ \\
\hline 21 & Metallurgic industry & $3.25 \mathrm{E}+10$ & $g / y r$ & 1.13E+10 & $f$ & $3.66 \mathrm{E}+20$ \\
\hline 22 & Mechanical industry & $2.12 \mathrm{E}+09$ & $\mathrm{~g} / \mathrm{yr}$ & $2.10 \mathrm{E}+10$ & $m$ & $4.46 \mathrm{E}+19$ \\
\hline 23 & Mineral industry & $1.04 \mathrm{E}+10$ & $\mathrm{~g} / \mathrm{yr}$ & $3.09 E+09$ & $n$ & $3.21 \mathrm{E}+19$ \\
\hline 24 & Chemical industry & $2.64 \mathrm{E}+11$ & $\mathrm{~g} / \mathrm{yr}$ & $6.38 \mathrm{E}+08$ & 0 & $1.68 \mathrm{E}+20$ \\
\hline 25 & Rubber industry & $3.53 E+10$ & $\mathrm{~g} / \mathrm{yr}$ & $7.22 \mathrm{E}+09$ & $f$ & $2.55 \mathrm{E}+20$ \\
\hline \multirow[t]{2}{*}{26} & Other manifacturing industries & $1.25 \mathrm{E}+10$ & $\mathrm{~g} / \mathrm{yr}$ & $5.81 \mathrm{E}+09$ & $h$ & $7.28 \mathrm{E}+19$ \\
\hline & & & & & & $1.33 \mathrm{E}+22$ \\
\hline \multicolumn{6}{|c|}{ IMPORTED RESOURCES (GOODS and MATERIALS), F2 (sum of items 1-26) } & $1.47 \mathrm{E}+22$ \\
\hline
\end{tabular}

The total emergy use (U) for the Province of Pescara in 2001is 2.59E+22 sej/yr that depends on the variety of activities and dynamics occurring within the areas. The total annual emergy use is a measure of wealth; several activities of transformation industry, commerce, services, tourism, beside the density of people, let the value increase.

Locally available environmental inputs $(R)$ account for about $0.9 \%$ of total emergy supporting the Province of Pescara. Rain, tide, geothermal heat and hydroelectricity are included in the total renewable flow.

In particular, a fraction of electricity use can be considered renewable, because it is produced inside the Province from hydroelectric plant (with a production of $27,000,000 \mathrm{kwh}$ ); thermoelectricity produced in the Province have 
been considered non renewable and imported because fuel is not locally available (Table 1).

An additional contribution of $8.66 \mathrm{E}+21 \mathrm{sej} / \mathrm{yr}$ comes from local nonrenewable flows. Extractive activity plays a significant role according to the emergy accounting of the Province (in particular for the area of Crinale Centrale); the high amount of emergy contributed by extracted materials is due to their quantities and, especially, to the high values of their transformities. Local resources, both renewable and non-renewable, represent about $35 \%$ of the total emergy use in the area.

The total imported emergy $\mathrm{F}$ is $10.70 \mathrm{E}+22 \mathrm{sej} / \mathrm{yr}$, and is the sum of all the fluxes coming from the outside. It is about $66 \%$ of the total emergy used. This value is given by the sum of the emergy amount due to purchased energy and fuels F1 and purchased goods and materials F2.

Table 3: Emergy evaluation and indexes for the Province of Pescara and its areas, year 2001 .

\begin{tabular}{|c|c|c|c|c|c|c|c|c|}
\hline AREA & $\begin{array}{c}R \\
\text { sej/yr }\end{array}$ & $\begin{array}{c}\mathrm{N} \\
\text { sej/yr }\end{array}$ & $\begin{array}{c}F \\
\text { sej/yr }\end{array}$ & $\begin{array}{c}U \\
\text { sej/yr }\end{array}$ & $\begin{array}{c}\text { ED } \\
\text { U / area }\end{array}$ & $\begin{array}{c}\text { EpP } \\
\text { U/pop }\end{array}$ & $\begin{array}{c}\text { ELR } \\
N+F / R\end{array}$ & $\begin{array}{l}\text { EIR } \\
F / L\end{array}$ \\
\hline PROVINCE OF PESCARA & $2.16 \mathrm{E}+20$ & $8.66 \mathrm{E}+21$ & $1.70 \mathrm{E}+22$ & $2.59 \mathrm{E}+22$ & $2.11 \mathrm{E}+13$ & $8.76 E+16$ & 118.92 & 1.92 \\
\hline COSTA & $2.55 \mathrm{E}+19$ & $9.40 \mathrm{E}+20$ & $7.67 \mathrm{E}+21$ & $7.50 \mathrm{E}+21$ & $4.66 \mathrm{E}+13$ & $3.99 \mathrm{E}+16$ & 338.02 & 7.95 \\
\hline CRINALE CENTRALE & $3.35 E+19$ & $4.38 \mathrm{E}+21$ & $5.21 \mathrm{E}+21$ & $1.03 E+22$ & $4.76 \mathrm{E}+13$ & $3.05 \mathrm{E}+17$ & 286.06 & 1.18 \\
\hline GRAN SASSO & $3.19 \mathrm{E}+19$ & $6.36 \mathrm{E}+18$ & $8.20 \mathrm{E}+20$ & $7.04 \mathrm{E}+20$ & $3.42 E+12$ & $7.89 \mathrm{E}+16$ & 25.86 & 21.40 \\
\hline MAJELLA & $7.26 \mathrm{E}+19$ & $2.29 \mathrm{E}+21$ & $1.08 \mathrm{E}+21$ & $4.11 \mathrm{E}+21$ & $1.35 E+13$ & $2.33 E+17$ & 46.42 & 0.46 \\
\hline TREMONTI & $1.75 E+19$ & $1.29 \mathrm{E}+20$ & $5.73 \mathrm{E}+20$ & $6.58 \mathrm{E}+20$ & $5.82 E+12$ & $4.28 \mathrm{E}+16$ & 40.12 & 3.92 \\
\hline VESTINA & $3.47 \mathrm{E}+19$ & $9.20 \mathrm{E}+20$ & $1.64 \mathrm{E}+21$ & $2.63 E+21$ & $1.17 \mathrm{E}+13$ & $8.28 E+16$ & 73.82 & 1.72 \\
\hline
\end{tabular}

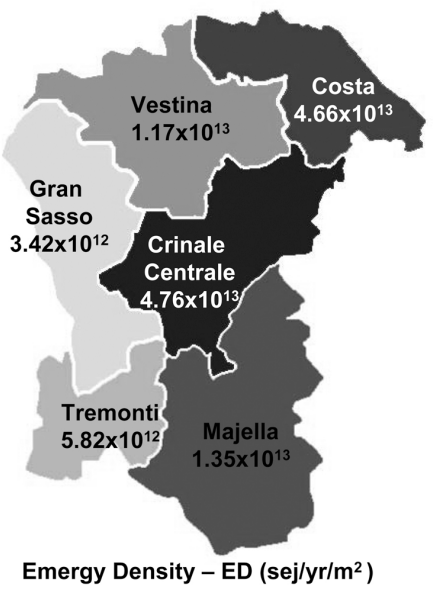

Figure 1: Maps of emergy density and environmental loading ratio in the Province of Pescara.

This high percentage of resources coming from the outside means that there is a presence of many local entities that import resources from a huger context. 
Once all the inputs have been classified into categories, some indicators are calculated. Each area has been investigated, and the results of the analysis are shown in Table 3, that shows also a comparison between the Province of Pescara and the six districts with different environmental and economic characteristics.

Only a deep investigation of all the values, ratios and indicators, besides the first collection of data, allow to understand the real behaviour of each area and its role within the system. This outcome gives a clear vision of resource consumption throughout the area of the Province. Results are not homogeneous and show different conditions in different areas. Two districts (Crinale Centrale and Costa) have been highlighted as areas where very concentrated flows of emergy are located, due to the population density and the presence of industrial activities, high urbanization and resource use and extraction.

The values of the emergy density $\left(2.11 \mathrm{E}+13 \mathrm{sej} / \mathrm{yr} / \mathrm{m}^{2}\right)$ and the emergy per person $(8.76 \mathrm{E}+16 \mathrm{sej} / \mathrm{yr} / \mathrm{ab}$.) for the Province and for each district help to estimate respectively the pressure of the economic activity on the territory and the standards of living in terms of availability of resources.

The measure of spatial stress, represented by ED, is higher in Costa $\left(4.66 \mathrm{E}+13 \mathrm{sej} / \mathrm{yr} / \mathrm{m}^{2}\right)$ and Crinale Centrale $\left(4.76 \mathrm{E}+13 \mathrm{sej} / \mathrm{yr} / \mathrm{m}^{2}\right)$ than in the Province of Pescara as a whole. Low levels are found in Gran Sasso (3.42E+12 $\left.\mathrm{sej} / \mathrm{yr} / \mathrm{m}^{2}\right)$.

The Emergy per Person (EpP) shows how consumption is related to population and, in a certain sense, this index represents the responsibility of each inhabitant for the use of resources. The values for the Province of Pescara and its districts Costa and Tremonti show a certain equilibrium between local consumption and the presence of population; a high level of population density is compensated by a moderate amount of resources per capita. The high value in Crinale Centrale derives from the existence of a relevant level of exploitation of local non-renewable resources.

The Province of Pescara presents a high level of ELR, which reflect a larger use of local non-renewable resources. This indicator achieves high values in areas such as Crinale Centrale and Costa. So, a large ratio suggests a high level of environmental stress. Gran Sasso has lower values than other areas.

The emergy investment (EIR) ratio is the ratio of the emergy feedback from the economy to the indigenous emergy inputs. A high level of the EIR in Gran Sasso represents a sort of fragility of the system because of its dependence on inputs from other economic systems and probably depends on tourism. In Majella there is a low level of purchased resources with respect to the local resource availability.

\section{Conclusions}

The combined use of emergy synthesis, sustainable indicators, thermodynamics, is capable of providing synergic information on the dynamics of human systems at any level. According to this information so provided, future strategic choices have to be directed in order to enhance the welfare of the local community and orient the consumption of resources. Environmental and landscape information, 
social information from statistical database can be fruitfully integrated within the conceptual framework of emergy synthesis, contributing to local policy making, as well as to understand the relation between local and "sub-local" economies. The real application of the eMergy analysis during the planning practices concerns practical choices even interacting with other actors, urban planners, stakeholders and policy makers.

The best solutions are obviously the ones that decrease the value of the eMergy flows, that means decreasing consumptions of energy and matter within the local human settlement.

The general results for the Province of Pescara suggest that compatibility between some economic activities and increasing environmental protection is possible, provided that the population density is relatively low and that local renewable sources are used to a considerable extent. Sustainable economic activities can provide economic support to the local population, thus preventing people from abandoning a territory for better living conditions. A better use of environmental resources can maximize the total resource available and may increase economic vitality.

\section{References}

[1] Odum H.T., Environmental accounting: emergy and environmental decision making. Wiley, New York, US, 1996.

[2] Odum H.T., Brown M.T. \& Williams S.B., Handbook of emergy evaluation: a compendium of data for emergy computation issued in a series of folios. Folio \#1 - Introduction and Global Budget. Center for Environmental Policy, University of Florida, Gainesville, FL, 2000.

[3] Tiezzi E. (Ed.), Implementazione di un sistema di contabilità ambientale su scala provinciale e intercomunale. Experimental project sponsored by Italian Minister for the Environment. University of Siena and Province of Bologna, Bologna, Italy. 2001.

[4] Bastianoni S., Campbell D., Susani L. \& Tiezzi E., The solar transformity of oil and petroleum natural gas. Ecological Modelling 186, 2005, 212220.

[5] Ulgiati S., Odum H.T. \& Bastianoni S., Emergy analysis of Italian agricultural system: the role of energy quality and environmental inputs. (Eds.) Bonati L, Cosentino U, Lasagni M, Moro G, Pitea D ad Schiraldi A. Proc. 2nd Int. workshop - Trends in ecological physical chemistry. Elsevier, Amsterdam, The Netherlands, 1993, 187-215.

[6] Bastianoni S., Brown M.T., Marchettini N. \& Ulgiati S., Assessing energy quality, process efficiency and environmental loading in biofuels production from biomass. (Eds.) Chartier Ph, Beenackers A.A.C., and Grassi G. Proc. 8th European Biomass Conference - Biomass for energy environment, agriculture and industry. Pergamon, Oxford, 1994, 23002312.

[7] Brown M.T. \& Arding J.E., Transformity Working Paper. Center for Wetlands, University of Florida, Gainesville, FL, 1991. 
[8] Tiezzi E. (Ed.), Analisi di sostenibilità ambientale del Comune di Pescia. Unpublished report, Siena, Italy, 2000.

[9] Ulgiati S., Odum H.T. \& Bastianoni S., Emergy use, environmental loading and sustainability. An emergy analysis of Italy. Ecological Modelling 73, 1994, 215-268.

[10] Tiezzi E. (Ed.), Studio per un progetto di valutazione di scenari per uno sviluppo sostenibile della Laguna di Venezia, Unpublished report, Siena, Italy, 2000.

[11] Odum H.T., Emergy and Public Policy (Part I-II). Environmental Engineering Sciences, University of Florida, Gainesville, FL, 1992.

[12] Odum H.T. \& Odum E.C., Ecology and Economy. Emergy Analysis and Public Policy in Texas. Lyndon B. Johnson School of Public Affairs, Policy Research Project Report n. 78. Austin, TX, 1987.

[13] Odum H.T. \& Arding J.E., Emergy analysis of shrimp mariculture in Ecuador. Department of Environmental Engineering Sciences, University of Florida, Working paper prepared for Coastal Resources Center, University of Rhode Island, Narragansett, RI, 1991.

[14] Odum H.T. \& Odum E.C., Energy Analysis Overview of Nations. WP-8382, International Institute for Applied Systems Analysis, Laxenburg, Austria, 1983.

[15] Bjorklund J., Geber U. \& Rydberg T., Emergy analysis of municipal wastewater treatment and generation of electricity by digestion of sewage sludge; a Swedish case study. Resources Conservation \& Recycling 31 (4), 2000, 293-316.

[16] Bastianoni S., Marchettini N., Principi I. \& Tiezzi E., Sviluppo di un modello di analisi emergetica per il sistema elettrico nazionale. Unpublished report, Siena, Italy, 2001. 